Bothalia, 10, 4: 595-598.

\title{
The Current Status of Mistbelt Mixed Podocarpus Forest in Natal
}

\author{
by \\ E. J. Moll*
}

\begin{abstract}
The known distribution and history of Mistbelt Mixed Podocarpus Forest in Natal, and its utilization and destruction are discussed. It is suggested that there may be a general drying of the forest climate, which is supported by evidence from canopy tree growth and regeneration. That this generally drier period has contributed to the rapid rate of forest degradation is postulated, and the need for the immediate implementation of conservation measures to ensure the safety of a representative area of forest is stressed.
\end{abstract}

\section{DEFINITION AND Distribution}

Mistbelt Mixed Podocarpus Forest was the name given by Edwards (1967) in his survey of the vegetation of the Tugela Basin, for the climatic climax forest vegetation of the Natal Mistbelt. Previously this forest type had been variously called High Timber Forest (Fourcade, 1889), Yellow Wood Bush (Bews, 1912) and Temperate Forest (Pentz, 1945; Acocks, 1953). It generally occurs between about $3500 \mathrm{ft}$ (1000 $\mathrm{m})$ and 4500 to $5000 \mathrm{ft}(1300$ to $1500 \mathrm{~m})$, on steep south-facing slopes. These slopes are subject to relatively frequent mist, particularly in summer, (hence the name 'mistbelt'), and the rainfall is good (at least $1000 \mathrm{~mm}$ a year), so the region is relatively moist. Temperatures are equable, with low maxima (about $37^{\circ} \mathrm{C}$ ), high minima (about $-4^{\circ} \mathrm{C}$ ), and an annual mean of about $16^{\circ} \mathrm{C}$ (Weather Bureau, 1954). Moderately severe frosts occur on level ground, but probably not on the steep slopes on which the forest is situated. Snow does occur occasionally, and the rare heavy falls can cause great mechanical damage (Moll, 1965).

As the name suggests, the most important tree species are, or were, Podocarpus spp. Many associated tree species occur, such as Ptaeroxylon obliquum, Celtis africana, Calodendrum capense, Olea capensis, Cussonia chartacea, Cryptocarya myrtifolia, Prunus africanus, Xymalos monospora, Kiggelaria africana and Combretum kraussii.

Mistbelt Mixed Podocarpus Forest represents one of a series of three montane forest types found in Natal. Montane Podocarpus Forest occurs at higher altitudes, it is physiognomically and structurally reduced, and floristically depauperate (Moll, 1965; Edwards, 1967), The Inland Sub-tropical Forest types (Acocks, 1953) occur at lower altitudes and further north, and have greater floristic affinity with the Tropical Forests.

In Natal, Mistbelt Mixed Podocarpus Forest occurs from Qudeni in the north, to the Ingeli and Impetyne Forests in the south (Fig. 1).

\section{UTILIZATION}

We know from various historical accounts, summarized relatively recently by Rycroft (1942), Moll (1965) and Edwards (1967), that the Mistbelt Mixed Podocarpus Forests of Natal were intensively worked for timber until about 1940. The chief species cut were Podocarpus spp., Ocotea bullata, Ptaeroxylon obliquum and Olea capensis. In addition poles, laths and saplings were taken out by the thousand for hut-building timber by the Bantu. Exploitation was not limited to severe tree cutting, the results of which are still exhibited by the irregular forest canopy, but also to the utilisation of forest areas as winter grazing for cattle - a practice which has a definite detrimental effect on regeneration (Taylor, 1961, 1962). The practice of burning the grassland surrounding the forest, without due precaution for the protection of the forest margins, has also contributed to forest destruction.

* Botanical Research Institute, Department of Agricultural Technical Services, Durban Unit, Botanic Gardens Road, Durban. 


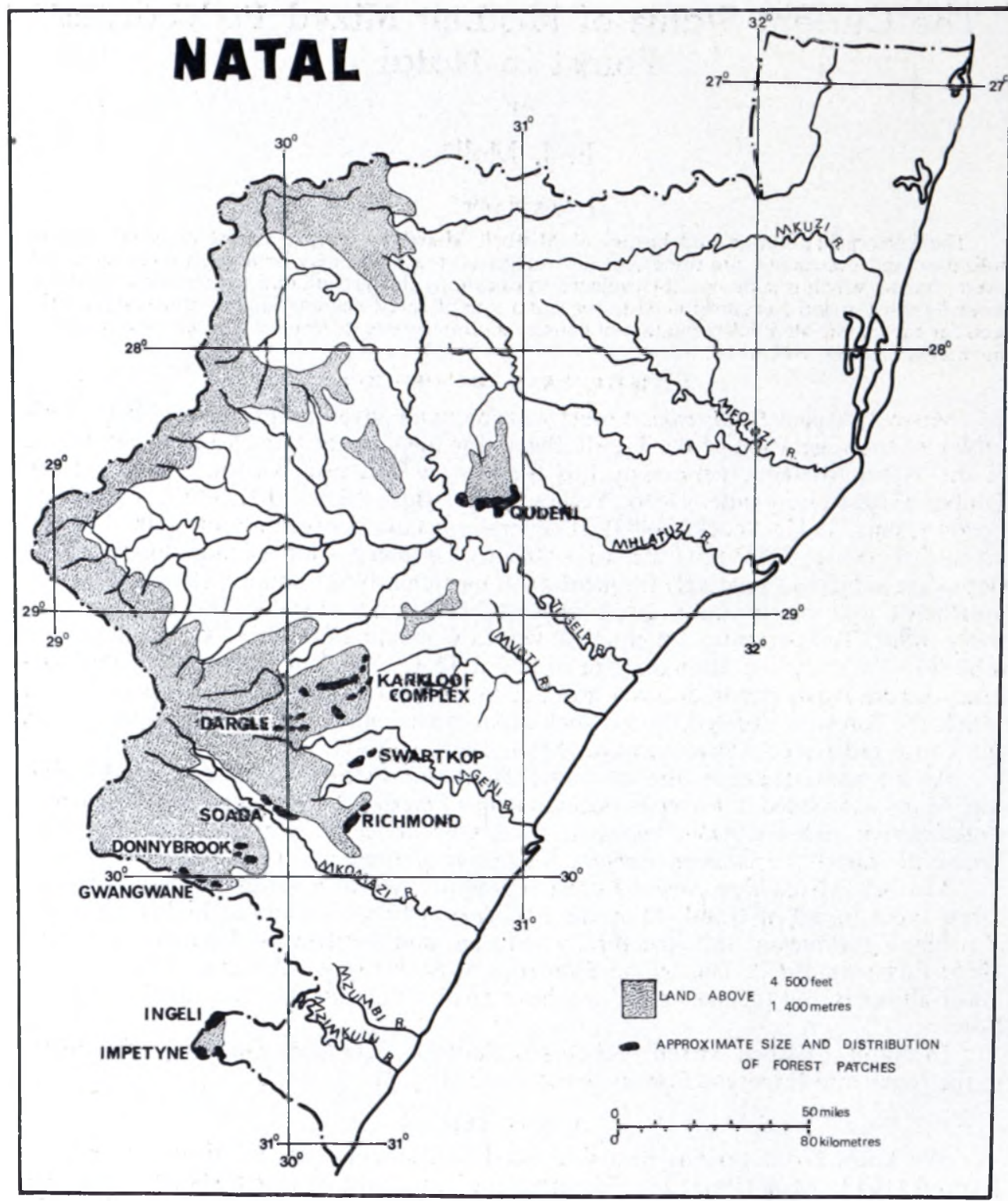

Fig. 1.-Map showing size and distribution of patches of Mistbelt Mixed Podocarpus Forest in Natal.

Today it is generally accepted that the major factor causing the reduction in size of our Mistbelt Mixed Podocarpus Forests is man. Taylor (1961) pleaded for the protection of the Karkloof Forest, which covered an estimated 80000 acres in 1880 (Fourcade, 1889) and had greatly diminished to an estimated 15000 to 20000 acres by the early 1940's (Rycroft, 1944). Rycroft suggests that even if the 1880 estimate was high, it does mean that there might have been as much as $80 \%$ reduction of forest area in only 60 years, the chief factors causing this reduction being fire and over-exploitation. Taylor (1963) in a report on the Nxamalala Forest states that this forest, which was about 8000 acres in area in 1880, had been reduced to a mere 1500 acres 70 years later. 


\section{Óbservations on Canopy Tree Growth and Regeneration}

In 1929 the resident forester at Xumeni Forest, near Donnybrook, laid out a line through the forest and on it recorded the circumference at breast height of all trees in 40 one chain square, systematically placed plots. In 1966, 37 years later, the same trees were re-measured (Moll \& Woods, 1971). The results showed that the mean increment rate was very slow, $0,201+0,05(\mathrm{n}+160)$ inches $(5,10=0,127 \mathrm{~mm})$ in circumference per year. Common trees at Xumeni are Podocarpus henkelii, Kiggelaria africana, Xymalos monospora, Podocarpus falcatus and Fagara davyi. Of these species, $F$. davyi, $P$. falcatus and $K$. africana grew the fastest.

Moll \& Haigh (1966) wrote of Xumeni that, "regeneration was poor, and it would appear that, under natural conditions, regeneration is not sufficient to maintain the forest". Xumeni Forest has been protected by the Department of Forestry since 1910.

In 1967/1968 Moll (in preparation) collected density data of all woody plants from twelve $40 \times 40 \mathrm{~m}$ stands in the Karkloof Forest. The data indicated that the species regenerating were not those species that are presently important in the canopy. Common canopy trees in the Karkloof at present are, Xymalos monospora, Podocarpus latifolius, Celtis africana, Calodendrum capense, Fagara davyi, Kiggelaria africana, Podocarpus falcatus and Ptaeroxylon obliquum. Canopy tree species most common as young trees are Ptaeroxylon obliquum, Podocarpus latifolius, Olea capensis, Podocarpus falcatus, Vepris undulata and Celtis africana, while canopy tree species most common as seedlings and young saplings are $V$. undulata, $P$. obliquum, $P$. latifolius and $C$. africana. This means that species such as $X$. monospora, $C$. capense, $F$. davyi and $K$. africana are not regenerating and in future years will be unimportant canopy trees.

Taylor (1961) observed that on Miss Morton's farm in the Karkloof there were many seedlings of Celtis africana, Cussonia chartacea and Ptaeroxylon obliquum. He also noted that where cattle grazed the forest the tree seedlings were unable to advance, and that the two species common at Morton's, Podocarpus henkellii and Ocotea bullata, were not regenerating.

Moll (1965) observed that regeneration in the Dargle forests was restricted to Podocarpus falcatus, $P$. latifolius and Ptaeroxylon obliquum.

The general conclusion which can be drawn from these observations is that the species regenerating are those capable of tolerating a drier climate. Added to this, in areas of forest which have been protected, such as Xumeni which has been protected for the last 60 years, regeneration is poor. Seedling density in the Karkloof of 48 Vepris undulata, 32 Ptaeroxylon obliquum and 16 Podocarpus latifolius per hectare, is not indicative of active regeneration, not when one compares this to seedling densities in actively regenerating forests on the coast, such as at Hlogwene (Moll, in preparation) where, for example, there are 131 Olea woodiana and 94 Strychnos decussata seedlings per hectare. In addition, seedlings of trees which prefer a cool moist environment, such as Ocotea bullata and Podocarpus henkelii, are extremely rare.

\section{Factors Contributing to a Drier Forest Climate}

Moreau (1966) states that in the last 18000 years the temperatures in Africa have risen by $5^{\circ} \mathrm{C}$. Stuckenberg (1969) quotes Van Zinderen Bakker (1963), who states, "It has often been said that changes in temperature of the magnitude of only $5^{\circ} \mathrm{C}$ are of minor importance in a tropical continent such as Africa. These changes have, however, been of very great significance........ Little but consistent changes of this nature can have an enormous influence on the distribution of plants and animals." Stuckenberg also quotes Bailey (1960), who states that these temperature changes affect maritime climates most. The Mistbelt Forests in Natal are influenced to a considerable degree by weather from the Indian Ocean. 
Accepting a rise in temperature of $5^{\circ} \mathrm{C}$ during the last 18000 years means that evaporation alone would be greatly increased. The mountain biomes which were more extensive are now much reduced; the montane limit, according to Moreau (1966), was about $2300 \mathrm{ft}(700 \mathrm{~m})$, and is now $5000 \mathrm{ft}(1500 \mathrm{~m})$. Acocks (1953) also suggests that forest and scrub forest has largely disappeared in Natal, and that the drier vegetation types of bushveld and grassveld have greatly increased (see Acocks's Maps 1 \& 2).

In addition to climatic changes, natural fires, and more especially man-made fires, have become more numerous and these too have contributed to forest destruction; both directly and also indirectly, by increasing runoff. Furthermore, cattle grazing in the forests not only eat and trample the vegetation, but also open up the margins, allowing wind to penetrate beneath the canopy and fires to enter protective marginal vegetation.

\section{Preservation Requirements}

Referring again to Acocks (1953), we are warned that unless our vegetation is scientifically managed the drier vegetation types will expand further. If we are to preserve an example of Mistbelt Mixed Podocarpus Forest we will, therefore, have to manage it." It has been shown by a few conservation minded farmers who live in the Karkloof and Dargle areas that indigenous trees, such as Ocotea bullata and Podocarpus henkelii, if planted and cared for, grow relatively rapidly. However, the first priority is to have a sufficiently large area of forest proclaimed as a Nature Reserve. Once this has been achieved active management must include tree planting, run-off retention and protection of the margin from fire. Also large grazing and browsing animals must be excluded from the forest. Such management would have to be linked to a scientific monitoring programme, designed to measure which management practices are most beneficial in insuring maximum forest development.

\section{REFERENCES}

Acocks, J. P. H., 1953. Veld types of South Africa. Mem. Bot. Surv. S. Afr. No. 28.

Bews, J. W., 1912. The vegetation of Natal. Ann. Natal Mus. 2: 253-331.

Edwards, D., 1967. A plant ecology survey of the Tugela Basin. Mem. Bot. Surv. S. Afr. No. 36.

FourCADE, H. G., 1889. Report on the Natal forests. Natal Blue Book. Pietermaritzburg: W. Watson.

Moll, E. J., 1965. An account of the plant ecology of the Upper Mgeni Cathcment. Unpublished M.Sc. thesis, University of Natal, Pietermaritzburg.

Moll, E. J., (in preparation). A quantitative ecological study of the Karkloof Forest, Natal.

Moll, E. J., (in preparation). A quantitative floristic comparison of four Natal forests.

Moll, E. J. \& Woods, D. B., 1971. The rate of forest tree growth and a forest ordination at Xumeni, Natal. Bothalia 10: 451-460.

Moreau, R. E., 1966. The bird faunas of Africa and its Islands. Academic Press.

Pentz, J. A., 1945. An agro-ecological survey of Natal. Dept. Agric. and For. Bull. No. 25, Govt Printer, Pretoria.

RycrofT, H. B., 1942. The plant ecology of the Karkloof Forest, Natal. Unpublished M.Sc. thesis, University of Natal, Pietermaritzburg.

Rycroft, H. B., 1944. The Karkloof Forest, Natal. J. S. Afr. Forestry Association. 11.

StUCKenberG, B. R., 1969. Effective temperature as an ecological factor in Southern Africa. Zoological Africana. 4 (2): 145-197.

TAYLOR, H. C., 1961. The Karkloof Forest, a plea for its protection. Forestry in S. Afr. 1: 123-134.

TAYLOR, H. C., 1962. A report on the Nxamalala Forest. Forestry in S. Afr. 2: 29-51.

Weather Bureau, 1954. Climate of South Africa. Part 1. Climate Statistics. Govt. Printer, Pretoria.

* Only $0,8 \%$ of the total area of Acocks's (1953) "Temperate \& Transitional Forest and Scrub Types" is conserved (Edwards, 1971). 